\title{
Prospects for using nonconventional feeds in diets for Awassi dairy sheep in Syria
}

\author{
M. Hilali, ${ }^{\dagger}{ }^{1}$ L. Iñiguez, $\dagger$ W. Knaus, ${ }^{*}$ M. Schreiner, ${ }^{*} B$. Rischkowsky, $\dagger$ M. Wurzinger, ${ }^{\star}$ and H. K. Mayer ${ }^{\star}$ \\ *BOKU - University of Natural Resources and Applied Life Sciences, Gregor-Mendel-Strasse 33, A-1180 Vienna, Austria \\ †International Center for Agricultural Research in the Dry Areas (ICARDA), PO Box 5466, Aleppo, Syria
}

\section{ABSTRACT}

High feed costs are major obstacles for resource-poor dairy sheep farmers in West Asia, along with large fluctuation in grain and straw prices. Farmers need lowcost diets using locally available feeds that can provide sufficient milk of good quality. Two experimental trials were conducted on Awassi milking ewes to evaluate nonconventional and balanced low-cost diets against the traditional unbalanced diet used by farmers (control) on the total yields (milk, fat, protein, and total solids) and milk composition (fat, protein, total solids, and lactose), an important indicator of milk quality. The first trial was conducted at the research station of the International Center for Agricultural Research in the Dry Areas (ICARDA, Aleppo, Syria) to test 6 low-cost balanced diets using locally available feeds and agro byproducts against the control diet. Each diet was tested on 8 ewes that were kept on pasture as a basal diet, but received different supplements, including barley, wheat bran and nonconventional feeds (ureatreated wheat straw, molasses, sugar beet pulp, and cotton seed cake). Five balanced diets enhanced the total yields of milk, fat, protein, and total solids, in 2 cases, significantly. These diets increased total milk yield by 17.7 to $50.2 \%$ and decreased supplement feeding costs by $43 \%$ compared with the control. However, milk composition remained unaffected. The second trial was conducted on 3 different farms in northern Syria to assess in each farm a low-cost balanced diet on milking ewes $(\mathrm{n}=15)$ in comparison to the farmer's control ( $\mathrm{n}$ $=15$ ). The balanced diet was a modification requested by farmers of the best performing diet in the on-station trial. Confirming the first trial's research results, the balanced diet outperformed the control in total yields; for instance, it increased total milk yield by 28 to $40 \%$ and raised net income by $30 \%$, without affecting milk composition. Both trials showed that using locally available nonconventional feedstuffs, such as molasses,

Received June 17, 2010.

Accepted February 28, 2011.

${ }^{1}$ Corresponding author: m.hilali@cgiar.org integrated into balanced dairy sheep diets can decrease feed costs of resource-poor farmers, while enhancing total yields of milk and milk constituents without compromising milk quality components. This will greatly improve the profitability of dairy sheep production in dry areas.

Key words: Awassi sheep milk, nonconventional feed, milk yield

\section{INTRODUCTION}

Sheep production plays an important role in supporting the livelihood of resource-poor farmers in the low-rainfall regions of the Middle East. Frequently affected by severe droughts, farmers from these regions suffer from periods of intense feed scarcity, aggravated by a decrease in the productivity of ranges and the increasing effects of climate change (Ben Salem and Smith, 2008). In parallel, a significant increase in human populations and market demand has increased the demand for products from small ruminants, particularly for cheese and yogurt, which are traditionally and widely consumed in the region. It is assumed that this expansion offers opportunities for farmers to enhance their livelihoods (Delgado et al., 1999; Iñiguez, 2005).

To overcome feed scarcity constraints and to increase the benefits from market opportunities, most farmers resort to expanding periods of costly feed supplementation, particularly using barley grain and straw, in addition to expensive feedstuffs, some imported from abroad. Farmers therefore state that feeding costs represent the most limiting constraint, exacerbated by increasing prices of barley grain and straw in recent years (Hartwell et al., 2010).

Some agricultural byproducts, such as sugar beet pulp (SBP; Schei et al., 2005), cotton seed cake (Şahin et al., 2003), olive cake, and tomato pulp (Ben Salem and Znaidi, 2008), have been introduced into animal diets in the Mediterranean region (Ben Salem et al., 2004; Blache et al., 2008; Vasta et al., 2008). However, these are not yet being widely used in developing Middle Eastern countries where they are produced, although they are available at lower cost as compared 
with more expensive traditional feeds such as barley grain and straw.

The International Center for Agricultural Research in the Dry Areas (ICARDA) has successfully developed strategies that decrease feeding costs for lamb-fattening systems, using some low-cost feeds available in the region (Rihawi et al., 2010). It was proposed that the use of these strategies be extended to Awassi dairy sheep production, in particular during the milking season when the dependency on expensive feedstuffs is acute. As effects of feed composition on milk yield and composition and on cheese yield and quality in sheep and goats have been shown in other studies (Bencini, 2001), it was necessary to evaluate the alternative diets containing nonconventional feedstuffs in relation to milk productivity and product quality, to avoid risks to farmers that may endanger their market interactions.

This study assessed the effects of using low-cost balanced diets containing conventional and nonconventional feeds produced in the Middle East on Awassi sheep milk yield, the quality of milk and milk products, and on farm incomes. These diets were compared with the more expensive traditional diet used by farmers, also known to provide a surplus of ME, and an unbalanced CP:ME ratio (Al-Jassim et al., 1999; Nefzaoui et al., 2008). Our argument was that the traditional and expensive diet could be modified by balancing it, utilizing low-cost nonconventional feeds, according to animal requirements, without compromising and eventually enhancing the productivity and quality of the milk, and thus, the economic sustainability of dairy sheep farming. Our hypothesis was that the inclusion of nonconventional feeds in supplemental diets of Awassi dairy sheep would not have a negative effects on milk yield and milk composition compared with farmers' traditional unbalanced diets and a conventional balanced diet.

\section{MATERIALS AND METHODS}

Two experiments, one on-station and one on-farm, were conducted in 2007 and 2008, respectively. The objective of the on-station experiment was to evaluate the performance of different diets containing a variety of nonconventional feed ingredients. The subsequent on-farm experiment aimed at testing and validating the performance of the most promising diet (selected from the on-station experiment) under farm conditions.

\section{On-Station Experiment}

Prior to setting up the on-station trial, participatory tools were used in focal workshops involving 58 farmers in northern Syria, to identify the average type of diet used by farmers during the milk production period (control diet).

A total of 56 milking ewes, aged from 3- to 6-yr old and in their second or greater parity, from ICARDA (Aleppo, Syria) Awassi experimental flock, were used in the experiment. The ewes were weaned at $56 \pm 3 \mathrm{~d}$ after parturition, and were $67 \pm 15$ DIM at the outset of the experiment.

Seven diets (6 experimental diets and the control diet) were compared through 7 corresponding diet groups of ewes, each consisting of 8 Awassi ewes. The control diet consisted of an average diet used by farmers in the area which involves range grazing (RG) as basal diet and the use of a supplement containing conventional feeds: barley, wheat bran, and barley straw, whereas the 6 experimental diets involved RG or grazing on vetch (Vicia sativa) pasture (VP), and the use of supplements based on different nonconventional feeds: cotton seed cake (CSC), molasses (M), SBP, and urea-treated straw (UTS). Specifically, the defined experimental diets (Table 1) included

1. CSC: RG and a supplement having similar ingredients as the control diet, except that it contained CSC to decrease the use of barley grain,

2. M-SBP-UTS: RG and a supplement including $\mathrm{M}$, SBP, UTS, and CSC to decrease the use of barley grain and replace barley straw,

3. CSC-UTS: RG and a supplement with similar ingredients as the control, except that it contained CSC and UTS to decrease the use of barley grain and replace barley straw,

4. M-SBP: RG and a supplement similar to that of the second experimental M-SBP-UTS diet, except that it used only barley straw, as in the control,

5. M-SBP-CSC: RG and a supplement where the total use of barley grain was replaced by using M, SBP, CSC, wheat bran, and barley straw, and

6. M-SBP-VP: VP and a supplement based on M, SBP, wheat bran, and barley straw, where the total use of barley grain was also replaced.

The ewes were allocated to the 7 diet groups so that the means and variances for ewe liveweight, initial milk yield, and initial DIM, recorded before the outset of the experiment, were homogeneous among groups. Homogeneity of means and variances was confirmed by using the Bartlett test for homogeneity. Likewise, animals were distributed so that the distribution of litter size and age of ewes were similar in all groups.

The diets were formulated and fed to the animals from April until the end of the milking period, when the daily milk yield per ewe fell below $200 \mathrm{~mL}$ during 
Table 1. Ingredients of supplemental diets, pasture regimen, and the nutritional value of the diets in the on-station experiment

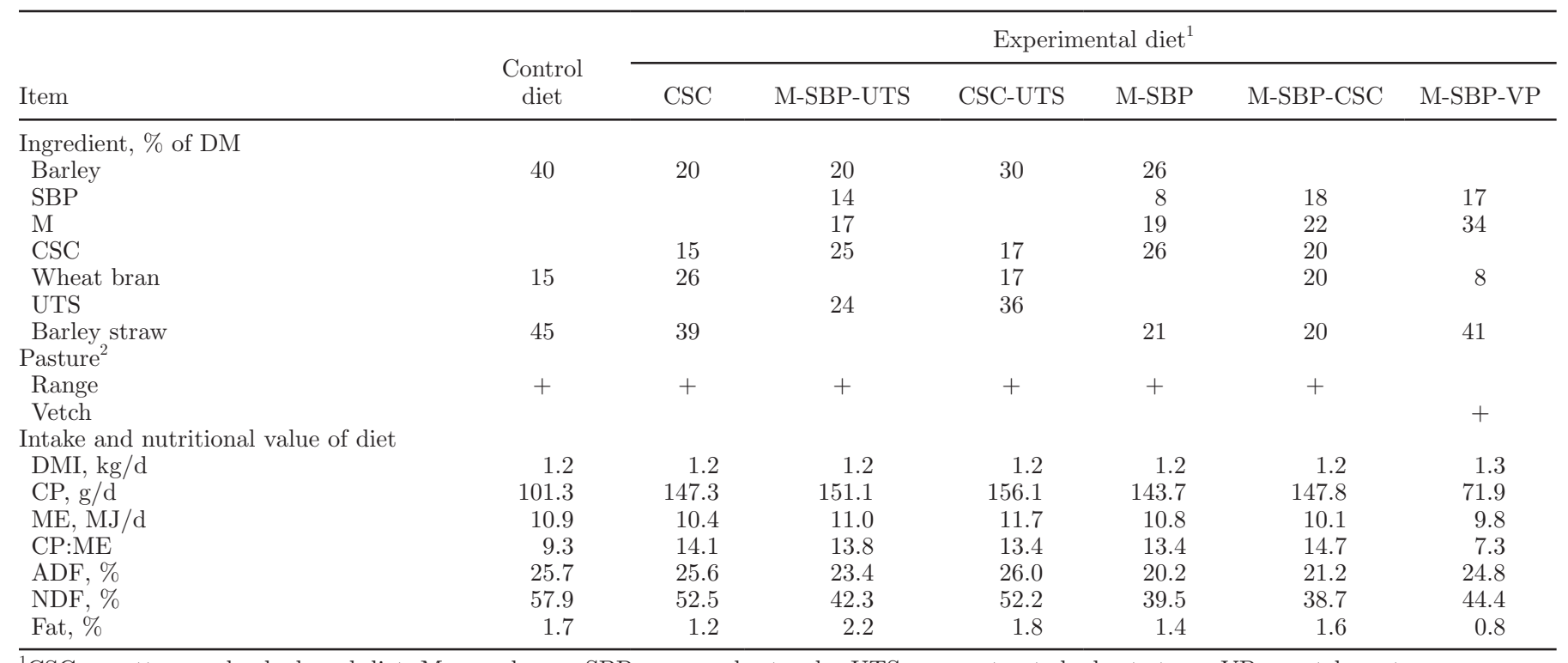

${ }^{1} \mathrm{CSC}=$ cotton seed cake-based diet; $\mathrm{M}=$ molasses; $\mathrm{SBP}=$ sugar beet pulp; UTS = urea-treated wheat straw; VP = vetch pasture.

${ }^{2}+$ Denotes application of the particular grazing type.

a single day (ICAR, 2007). At this time, the milking period was then recorded for each ewe. All ewes underwent the same management before the start of the experiment, under a standard diet consisting of pasture grazing with concentrate supplementation during the pre-weaning period.

Table 1 presents the supplements and grazing components of the treatment diets and the composition of the supplements for the control diet and the 6 experimental diets, formulated with conventional feeds (barley grain and wheat bran) and nonconventional feeds (UTS, M, SBP, and CSC). However, CSC could be considered as a conventional feed, as some farmers start to use it for dairy sheep feeding.

Animals from all groups were managed on weekly strip grazing (at a stocking rate of 54 ewe/ha per week) as a basal diet component, with unrestricted access to water, and supplemented with the experimental supplements detailed in Table 1. The ewes grazed on natural rangeland with the exception of those fed the M-SBPVP diet, where the ewes grazed on vetch (Vicia sativa).

It has been estimated that the grazing on rangeland covered $40 \%$ of the animal requirements (Cocks and Osman, 1996). On this basis, and according to their maintenance and production requirements (MAFF, 1987), each animal in the experimental diets received, on average, $229 \mathrm{~g}$ of $\mathrm{CP}$ and $18 \mathrm{MJ}$ of ME per day from both the supplement and pasture. Under the traditional feeding regimen (control), which was set to resemble the average diet used by farmers, ewes received less protein $(180 \mathrm{~g} / \mathrm{d})$ and similar energy levels as those fed with the experimental diets. The supplement in the control diet contained barley grain and wheat bran. In diet 6 , involving VP, the supplement contributed, on average, only $72 \mathrm{~g}$ of $\mathrm{CP}$ and 9.8 MJ of ME per day, as vetch was expected to cover the remaining $\mathrm{CP}$ and energy demands of ewes. Fifty percent of the supplement was offered in the morning before grazing, and the remaining $50 \%$ in the evening after milking.

\section{On-Farm Experiment}

Prior to the on-farm experiment, a participatory workshop was held in a representative village in northern Syria. The researchers explained to the farmers the experimental results achieved with low-cost alternative diets on-station, and then discussed the diets as well as the planned design of the on-farm experiment. Farmers opted for the ingredients used in the M-SBP-UTS diet as the most acceptable alternative to be tested against their own traditional diets. This was preferred by farmers as it decreased the use of barley grain by $50 \%$, and eliminated the use of barley straw. However, the formulated supplement of this diet contained different proportions of the ingredients used in the MSBP-UTS diet in the on-station trial (Table 2). This was because farmers argued that the small proportion of straw as in the M-SBP-UTS diet (24\%), could cause diarrhea and thus, they preferred a higher proportion $(50 \%)$ of this ingredient. Three farmers proposed by the community agreed to conduct the feeding experiment with their flocks. Considering maintenance and produc- 
Table 2. Ingredients of supplemental diets and their nutritional value in the on-farm experiment

\begin{tabular}{|c|c|c|c|c|}
\hline \multirow[b]{2}{*}{ Item } & \multicolumn{4}{|c|}{ Supplemental diet ${ }^{1}$} \\
\hline & Control 1 & Control 2 & Control 3 & Exp \\
\hline \multicolumn{5}{|l|}{ Ingredient, $\%$ of DM } \\
\hline Barley & 20 & 29 & 18 & 14 \\
\hline Wheat & & & 24 & \\
\hline Sugar beet pulp & 22 & 23 & 10 & 7 \\
\hline Molasses & & & & 9 \\
\hline Cotton seed cake & & & 14 & 20 \\
\hline Wheat bran & 16 & 12 & 12 & \\
\hline Urea-treated wheat straw & & & & 50 \\
\hline Barley straw & 41 & 43 & 30 & \\
\hline \multicolumn{5}{|c|}{ Intake and nutritional value of diet } \\
\hline DMI, kg/d & 1.99 & 2.15 & 2.15 & 1.49 \\
\hline $\mathrm{CP}, \mathrm{g} / \mathrm{d}$ & 174.4 & 181.3 & 277.7 & 177.4 \\
\hline $\mathrm{ME}, \mathrm{MJ} / \mathrm{d}$ & 19.2 & 21.1 & 22.7 & 12.7 \\
\hline CP:ME & 9.1 & 8.6 & 12.2 & 14.0 \\
\hline $\mathrm{ADF}, \%$ & 28.7 & 28.2 & 21.6 & 31.8 \\
\hline NDF, $\%$ & 58.6 & 58.7 & 44.6 & 54.0 \\
\hline Fat, $\%$ & 1.2 & 1.1 & 1.6 & 1.1 \\
\hline
\end{tabular}

${ }^{1}$ Control 1, 2, 3 = farmers' traditional diets on farm 1, farm 2, and farm 3, respectively; Exp = experimental diet.

tion requirements, each animal in the experimental diet should receive an average of $205 \mathrm{~g}$ of $\mathrm{CP}$ and $17 \mathrm{MJ}$ of ME per day (MAFF, 1987). It was estimated that grazing on natural pasture would cover only $25 \%$ of animal requirements, due the low rainfall in 2008.

Each farmer used his own traditional supplement and his own protocol for supplementing his ewes (Table 2), depending on his knowledge, access to communal grazing areas, and access to other feedstuffs. In preparing their supplements, all farmers used barley grain, wheat bran, SBP, and barley straw with differences in the individual composition.

For this trial, farmers made available 30 milking ewes, 3 - to 6 -yr old, in their second or greater parity. On each farm, animals were split into 2 groups, each consisting of 15 ewes, with no differences in the distributions of litter size and age of the ewe between groups. Following the on-station protocol strategy, ewes were allocated to groups so that means and variances for ewe liveweight and initial milk yield recorded before the outset of the experiment were homogeneous among groups, a condition also verified by the Bartlett test. No information on initial DIM was available, as the farmers did not record their animals' lambing dates. All ewes within a farm were treated the same, and managed under the farm's own management routine. Farmers grazed their animals in the early morning $(0600 \mathrm{~h})$ and brought them back to near their homes for the morning milking at $1000 \mathrm{~h}$. Then, from 1000 to $1500 \mathrm{~h}$, the groups were separated and offered some of their corresponding supplemental feed. After the evening milking $(1500 \mathrm{~h})$, farmers sent the animals back to graze again for about $5 \mathrm{~h}$ (1500 to $2000 \mathrm{~h}$ ). The ewes finally returned to the house barn to be separated and group-fed again. The experiment covered the period from March until the beginning of June. As with the on-station trial, recording of milk production was stopped when a ewe produced below $200 \mathrm{~mL}$ of milk per day (ICAR, 2007), time in which the milking period was also recorded per ewe basis.

\section{Assessment of Pasture and Vetch Composition}

Total biomass was measured weekly in each grazing plot from April to July, directly after the animals moved to the next plot. Total biomass was measured in areas protected by cages, and adjacent areas outside the cages. Ten cages $(0.6 \times 0.6 \times 0.5 \mathrm{~m})$ were distributed along 2 transects across each plot (Osman et al., 2006). Samples of vegetation were taken by cutting the plants with cutter blades at the soil level, and weighed after drying at $65^{\circ} \mathrm{C}$. Consumed biomass was calculated by subtracting available biomass outside cages from the total biomass inside cages (Osman et al., 2006). As farmers in the on-farm trial visited different grazing areas each day without much prior planning, pasture evaluation was conducted only in the on-station trial.

\section{Pasture and Feed Composition}

All pasture samples from the on-station trial and all diets used in the on-station and on-farm experiments were analyzed for DM, ash, fat, and CP content according to AOAC (2000), and ADF and NDF content according to Van Soest et al. (1991). In vitro digestibility was determined according to Tilley and Terry (1963). 


\section{Milk Measurements and Analysis}

In the on-station experiment, ewes were machine milked twice daily, at $0630 \mathrm{~h}$ and $1630 \mathrm{~h}$, using a double-12 milking parlor (Bonsaglia \& C., S.r.l., Brescia, Italy), except once per week when the ewes were hand milked to obtain milk yields and to collect milk samples for analysis. In the on-farm experiment, ewes were always hand milked at approximately 1000 and $1500 \mathrm{~h}$, and milk samples for analysis were collected once every 2 wk. The main milk components (\%), of fat, protein, lactose, and TS, were determined using a MilkoScan 133B device (Foss Electric, Hillerød, Denmark). Total milk yield $(\mathrm{kg})$ and the total yield $(\mathrm{kg})$ of fat, protein, TS, and lactose, were estimated for each ewe from the information gathered on recording days according to ICAR (2007).

\section{Statistical Analysis}

Statistical analyses were conducted using SAS software v. 9.1 (SAS Institute Inc., Cary, NC). The contribution of pasture to the animal diets for the first experiment was analyzed by linear models following the SAS GLM procedure, considering DMI, DM, and CP as dependent variables and the effects of the month of grazing as a fixed effect. The assessment of diet effects was also analyzed by linear models. In these models, total yield of milk, milking period, total yields of fat, protein, and TS, as well as the corresponding percentage of these components, were considered as the dependent variables; diets, age, and litter size, and their interactions as fixed effects; and the initial milk yield and initial DIM as covariates. The initial difference in animal liveweight within a treatment group proved not to be important as a covariate in the on-station experiment and, therefore, was not included in the models. Litter size and first- and second-order interactions between diets, litter size, and age were found to be not significant for all analyzed traits and, therefore, removed from the models.

Due to the nature of the on-farm experiment, a nested model with diets within farms was used, because the control diets were different on the 3 farms. In analyzing the same dependent variables listed for the first experiment, diets within farm were fitted as fixed effects and farms were treated as a random effect. The corresponding analysis followed SAS MIXED procedures. The initial DIM on-farm was not considered as a covariate, because the exact lambing date was not recorded. Resembling the on-station case, initial differences in ewe weight, litter size, and age of the ewes, and the corresponding interactions, did not cause any change in the analyzed variables and, therefore, were removed from the models; thus, only the initial milk yield was used as a covariate for the analysis. Estimated fixed effects in both experiments are presented as least squares means.

\section{Economic Analysis of Diets}

The economic performance of the diets was evaluated based on actual market prices for feeds and yogurt during the milking seasons 2007 and 2008, as farmers do not market fresh milk but only milk processed as yogurt. Net income was calculated by subtracting the daily costs from yogurt returns, and rates of return were calculated ( $\mathrm{Li}$ et al., 2008), using daily feed cost, and returns per animal from the sale of yogurt.

\section{RESULTS AND DISCUSSION}

\section{On-Station Experiment}

The nutrients provided by the rangeland and VP and the DMI decreased over time, from April to June, more so in the range than in the VP $(P<0.05$; Table 3$)$ affecting the total DMI (Table 4$)$.

Whereas the nutrients provided by the alternative experimental diets compensated for the drop in fodder quality and nutrient intake observed in the grazing plots, those provided by the control were insufficient to compensate for the $\mathrm{CP}$ decrease in the range $55.5 \%$ from April to May and an additional decline of $33.5 \%$ from May to June. The total daily intake per ewe from both pasture and supplement in the control group was 171 and $146 \mathrm{~g}$ of CP in May and June, respectively, with a CP:ME ratio of 9 in comparison to a CP:ME ratio of 12 in the groups of the experimental diets (Table 4). This corroborates previous findings that highlighted protein deficits in the traditional diets of small ruminants (Al-Jassim et al., 1999; Nefzaoui et al., 2008). Range and vetch vegetation were always available for grazing; therefore, the decrease in DMI from grazing was attributed to a combined effect of the decrease in forage quality and heat stress during this period (Settivari et al., 2007).

The effects of initial milk yield and initial DIM at the start of the trial, used as a covariate, were significant for milking period, total milk yield, and total yield of fat, protein, and TS (Table 5). As mentioned earlier, litter size and age of the ewe did not contribute to significant differences in any of the milk production traits analyzed. It is likely that the number of observations per age and litter size classes in this trial was too small to allow for a differentiation due to these effects.

Total milk yields of ewes fed diets CSC, M-SBPUTS, CSC-UTS, M-SBP, and M-SBP-CSC were 17.7 to $50.2 \%$ higher compared with ewes fed the control diet, 
Table 3. DMI, CP and ME intake, and fiber digestibility of range and vetch pasture in the on-station experiment

\begin{tabular}{|c|c|c|c|c|}
\hline \multirow[b]{2}{*}{ Pasture $^{1}$} & \multicolumn{3}{|c|}{ Month } & \multirow{2}{*}{$\begin{array}{l}\text { Significance } \\
\text { due to month } \\
\text { differences }\end{array}$} \\
\hline & April & May & June & \\
\hline \multicolumn{5}{|l|}{ Range } \\
\hline DMI, kg/d & $1.747 \pm 0.2^{\mathrm{a}}$ & $1.014 \pm 0.2^{\mathrm{b}}$ & $0.844 \pm 0.2^{\mathrm{b}}$ & $* *$ \\
\hline Grasses, $\%$ of DM & $42 \pm 10.3$ & $49 \pm 8.9$ & $57 \pm 7.9$ & NS \\
\hline Legumes, $\%$ of DM & $15 \pm 2.2^{\mathrm{a}}$ & $3 \pm 1.9^{\mathrm{b}}$ & $2 \pm 1.7^{\mathrm{b}}$ & $* *$ \\
\hline $\mathrm{CP}, \mathrm{g} / \mathrm{d}$ & $159.0 \pm 18.5^{\mathrm{a}}$ & $70.8 \pm 16.0^{\mathrm{b}}$ & $47.1 \pm 14.3^{\mathrm{b}}$ & $* *$ \\
\hline $\mathrm{ME}, \mathrm{MJ} / \mathrm{d}$ & $13.81 \pm 1.5^{\mathrm{a}}$ & $7.73 \pm 1.3^{\mathrm{b}}$ & $6.01 \pm 1.2^{\mathrm{b}}$ & $* *$ \\
\hline $\mathrm{ADF}, \%$ & $31.25 \pm 1.8^{\mathrm{b}}$ & $39.00 \pm 1.6^{\mathrm{a}}$ & $43.27 \pm 1.39^{\mathrm{a}}$ & $* *$ \\
\hline NDF, $\%$ & $49.70 \pm 3.8^{\mathrm{b}}$ & $59.56 \pm 2.3^{\mathrm{ab}}$ & $65.58 \pm 2.9^{\mathrm{a}}$ & $*$ \\
\hline Fat, $\%$ & $2.06 \pm 0.2$ & $2.30 \pm 0.2$ & $1.62 \pm 0.2$ & NS \\
\hline \multicolumn{5}{|l|}{ Vetch } \\
\hline DMI, kg/d & $1.272 \pm 0.1^{\mathrm{ab}}$ & $1.368 \pm 0.1^{\mathrm{a}}$ & $1.004 \pm 0.1^{\mathrm{b}}$ & * \\
\hline $\mathrm{CP}, \mathrm{g} / \mathrm{d}$ & $213.2 \pm 22.5$ & $211.1 \pm 19.5$ & $150.3 \pm 17.5$ & NS \\
\hline $\mathrm{ME}, \mathrm{MJ} / \mathrm{d}$ & $12.69 \pm 1.0^{\mathrm{a}}$ & $11.86 \pm 0.9^{\mathrm{a}}$ & $8.11 \pm 0.8^{\mathrm{b}}$ & $* *$ \\
\hline $\mathrm{ADF}, \%$ & $18.90 \pm 2.7$ & $23.30 \pm 2.4$ & $26.43 \pm 2.1$ & NS \\
\hline NDF, $\%$ & $32.44 \pm 2.7^{\mathrm{b}}$ & $37.82 \pm 2.4^{\mathrm{ab}}$ & $43.39 \pm 2.1^{\mathrm{a}}$ & $*$ \\
\hline Fat, $\%$ & $1.30 \pm 0.2$ & $0.68 \pm 0.2$ & $0.94 \pm 0.2$ & NS \\
\hline
\end{tabular}

$\overline{\mathrm{a}, \mathrm{b}}$ Least squares means within a row with different superscripts differ $(P<0.05)$.

${ }^{1}$ Values are averages of weekly measurements during the experimental period.

${ }^{*} P<0.05 ;{ }^{* *} P<0.01$.

though the increase was only significant in diets CSC and M-SBP-UTS (Table 5). This increase largely reflects the use of balanced diets with a balanced CP:ME ratio (in the case of diets CSC, M-SBP-UTS, CSC-UTS, M-SBP, and M-SBP-CSC), as opposed to the control diet with an unbalanced CP:ME ratio of less than 10 (Table 4), showing a deficit in protein which is known to lead to suboptimal milk production in ewes (Cowan et al., 1981). This finding also agrees with the results of Carnicella et al. (2008) in Maltese goats using a balanced diet with a pasture/concentrate ratio similar to that of the on-station trial. Gabler and Heinrichs (2003) stated that the relationship between protein and energy within the rumen can have a tremendous effect on the overall pattern of nutrient use. For a particular level of $\mathrm{ME}$, a critical CP intake to produce milk exists and the $\mathrm{CP}: \mathrm{ME}$ ratio increases with the increased levels of milk yield (Treacher and Caja, 2002). The effect of balancing $\mathrm{ME}$ and $\mathrm{CP}$ in diets CSC, M-SBP-UTS, CSC-UTS, $\mathrm{M}-\mathrm{SBP}$, and M-SBP-CSC was also translated into a longer milking period (24-43 d more), and more fat, protein, and TS produced than under the unbalanced control diet (Table 5). These results are expected, as an equilibrate diet does not deplete body reserves and,

Table 4. Total DMI from both grazing and supplement diets and its content of CP and ME

\begin{tabular}{|c|c|c|c|c|c|c|c|}
\hline \multirow[b]{2}{*}{ Item } & \multirow{2}{*}{$\begin{array}{c}\text { Control } \\
\text { diet }\end{array}$} & \multicolumn{6}{|c|}{ Experimental $\operatorname{diet}^{1}$} \\
\hline & & $\mathrm{CSC}$ & M-SBP-UTS & CSC-UTS & M-SBP & M-SBP-CSC & M-SBP-VP \\
\hline \multicolumn{8}{|l|}{ April } \\
\hline DMI, $\mathrm{kg} / \mathrm{d}$ & 2.9 & 2.9 & 2.9 & 2.9 & 2.9 & 2.9 & 2.6 \\
\hline $\mathrm{CP}, \%$ & 8.8 & 10.4 & 10.5 & 10.7 & 10.3 & 10.4 & 11.1 \\
\hline $\mathrm{ME} / \mathrm{kg}$ & 8.4 & 8.2 & 8.4 & 8.7 & 8.4 & 8.1 & 8.7 \\
\hline CP:ME & 10.5 & 12.7 & 12.5 & 12.4 & 12.3 & 12.8 & 12.7 \\
\hline \multicolumn{8}{|l|}{ May } \\
\hline DMI, $\mathrm{kg} / \mathrm{d}$ & 2.2 & 2.2 & 2.2 & 2.2 & 2.2 & 2.2 & 2.7 \\
\hline $\mathrm{CP}, \%$ & 7.8 & 9.9 & 10.0 & 10.2 & 9.7 & 9.9 & 10.6 \\
\hline $\mathrm{ME} / \mathrm{kg}$ & 8.4 & 8.2 & 8.5 & 8.8 & 8.4 & 8.1 & 8.1 \\
\hline CP:ME & 9.2 & 12.0 & 11.8 & 11.7 & 11.6 & 12.3 & 13.1 \\
\hline \multicolumn{8}{|l|}{ June } \\
\hline DMI, $\mathrm{kg} / \mathrm{d}$ & 2.0 & 2.0 & 2.0 & 2.0 & 2.0 & 2.0 & 2.3 \\
\hline $\mathrm{CP}, \%$ & 7.3 & 9.5 & 9.7 & 9.9 & 9.3 & 9.5 & 9.6 \\
\hline $\mathrm{ME} / \mathrm{kg}$ & 8.3 & 8.0 & 8.3 & 8.7 & 8.2 & 7.9 & 7.8 \\
\hline $\mathrm{CP}: \mathrm{ME}$ & 8.8 & 11.8 & 11.7 & 11.5 & 11.4 & 12.1 & 12.4 \\
\hline
\end{tabular}

${ }^{1} \mathrm{CSC}=$ cotton seed cake-based diet; $\mathrm{M}=$ molasses; $\mathrm{SBP}=$ sugar beet pulp; UTS = urea-treated wheat straw; $\mathrm{VP}=$ vetch pasture. 
therefore, permits a longer milking period (e.g., Cannas et al., 2002). For ewes fed diets CSC, M-SBP-UTS, CSC-UTS, M-SBP, and M-SBP-CSC, the increase in total yield of fat (14.1-45.6\%), protein (15.4-48.1\%), and TS (16.1-49.6\%), in comparison with the control diet, paralleled the increases in total milk yield. No significant differences were observed among the performance of ewes fed the experimental diets CSC, M-SBPUTS, CSC-UTS, M-SBP, and M-SBP-CSC in relation to total yields of milk, fat, protein, and TS. However, Diet CSC can be considered as a balanced traditional diet, as CSC is already used by some farmers. With the exception of the performance of ewes under diet M-SBP-VP, the total yields of milk, fat, protein, and TS observed under the remaining diets (Table 5), were within the range of values reported for Awassi sheep (Gursoy et al., 2001; Iñiguez and Hilali, 2009).

Except those ewes under the M-SBP-VP diet that recorded significantly the lowest fat and TS contents in milk, no significant differences were found in concentration of milk components with regard to the percentage of fat, protein, and TS between the alternative diets and between these and the control diet (Table 5). This can be explained by the ability of lactating ewes to mobilize their body reserves for maintaining milk production and milk quality as shown by Jaime and Purroy (1995) in a feeding trial with different $\mathrm{CP}$ levels. Whereas the contents of lactose among experimental diet groups did not differ $(P>0.05)$, lactose values were 6 to $9 \%$ lower in the control diet in relation to alternative diets. This finding concurs with Henno et al. (2008), who found that unbalanced diets, in particular diets with deficits in protein, cause low feed protein utilization in cows, reflected in lower lactose content in milk. It also shows that key components of milk quality are not affected when nonconventional feed ingredients are used as in the experimental diets CSC, M-SBP-UTS, CSC-UTS, M-SBP, and M-SBP-CSC.

Milk fat content found in this study was within the range reported by Galal et al. (2008). The average protein percentage of the milk produced by ewes under the balanced diets CSC, M-SBP-UTS, CSC-UTS, M-SBP, and M-SBP-CSC was slightly higher than that reported by Nudda et al. (2002) for Awassi ewes in Australia, whereas the average lactose percentage decreased into the range of averages found by these researchers. Milk protein content was higher than the range values reported by Galal et al. (2008).

Diet M-SBP-VP contained the highest level of $M$ $(35 \%)$ of the supplemental diets, and its use led to the lowest yields recorded for all milk production traits assessed in the trial $(P<0.01)$. In contrast, the use of $\mathrm{M}$ at more moderate levels (diets M-SBP-UTS, M-SBP and M-SBP-CSC) promoted adequate production per- 
formance. Fat and TS percentages in diet M-SBP-VP were 19.1 and $7.1 \%$ lower, respectively, than in the control (Table 5). Diets containing high amounts of soluble sugar, such as M, can accelerate fermentation, thereby causing a sharp decrease in rumen $\mathrm{pH}$, which can lead to impaired fiber digestion (Murphy and O'Mara, 1993) and, consequently, to a decreased acetate:propionate ratio that depresses the fat content (Van Soest, 1994; $\mathrm{Lu}$ et al., 2005). Protein digestibility depression caused by excesses of soluble sugar can also cause a decrease in milk yield (Preston, 1988).

The main advantages of using $\mathrm{M}$, a byproduct available in the region but not widely used in animal feeding, is to decrease costs while providing a suitable energy source. Results indicate that moderate levels as those proposed in diets M-SBP-UTS, M-SBP, and M-SBPCSC provide a suitable alternative to barley for dairy sheep feeding. Cotton seed cake is usually used as a protein source in fattening, but it is not widely used in dairy sheep in the region. Wheat straw is widely available in West Asia but has poor quality as fodder and its use is minimal compared with barley straw. Urea treatment of wheat straw enhances its nutritional quality, improving digestibility and protein content, resulting in a product similar to barley straw (Nurfeta et al., 2009), with which farmers are more familiar. Farmers are also familiar with SBP, an agro-industrial byproduct available in the region that in 2008 produced approximately 16.7 million $\mathrm{t}$ of sugar beet (FAO, 2010). However, it is clear farmers will have to adjust the composition of the diets described above according to actual market prices and availability.

\section{On-Farm Experiment}

Farmers change the traditional diets (control) as the milking season advanced to decrease costs. On average, the CP:ME ratios of the supplementary feeds offered in the traditional diets on the 3 farms were 8.8 on farm 1 , 8.7 on farm 2, and 12.5 on farm 3. All farmers started feeding their animals with similar amounts of feed. On average, they offer $2.24 \mathrm{~kg}$ of supplementary feed per ewe per day in March. In April, farmers on farm 1 and 2 decreased the quantity of supplementary feed by 26 and $38 \%$, respectively, with small changes in the mix composition to decrease costs, that led to a small difference in the CP:ME ratio (8.6). Even after this change, it could be assumed that the energy intake was higher than the animals' requirements, especially on farm 3, with a supplemented ME of $22.7 \mathrm{MJ} / \mathrm{kg}$.

The control unbalanced starchy diet and high temperatures from mid-May could divert the energy to body fat deposition and lead to a decrease in milk yield, because gluconeogenesis stimulation is followed by an increase in insulin and adipose tissue uptake capacity (Molle et al., 2008).

Milk yield at the start of the trial used as a covariate, was significant in all measured traits but did not have any effect on the length of the milking period (Table 6). The alternative experimental diet selected by farmers, which targeted a balanced nutritional level, though slightly increased the milking period in relation to the traditional diet $(P>0.05)$, promoted a substantive increase in total milk yield on each farm, from 28.1 to $40.4 \%(P<0.01)$. The alternative experimental diet enhanced the total yield of fat by 23.6 to $49.3 \%$, protein by 28.5 to $32.5 \%$, and TS by 26.6 to $42.6 \%$, as compared with the control diet within the same farm $(P<0.01)$. Diets rich in energy could lead to milk, fat, and protein yield depression, as observed in this and in the on-station experiment. Similar depression in milk yield and milk protein was reported for Sarda grazing sheep supplemented with ME levels resembling those used by farmers in the on-farm experiment (Molle et al., 2008), as well as in cows (Bargo et al., 2003). Farmers are unaware of their diets causing a potential depression on yields of milk that is transformed into yogurt and cheese, and fat that is processed into ghee, important products that substantially contribute to family income.

Production can be further enhanced if feeding with a balanced diet starts before lambing through early lactation, due to the higher milk production during early lactation, a time when homeorhetic changes in the hormonal system lead to the use of body reserves to produce milk in later stages of milking on a more sustained basis (Peel and Bauman, 1987).

No significant differences were found between the alternative diet and the control diet within farms, on the percentages of fat, protein, TS, and lactose (Table 6). These findings confirm that the traditional diet could be modified as in the alternative diet, without affecting key quality components of the milk.

\section{Economic Analysis}

Considering yogurt and feed prices for 2007, the economic performance estimated as net income per ewe promoted by diets CSC, M-SBP-UTS, CSC-UTS, and M-SBP in the on-station trial was 28 to $57 \%$ higher than the control. Diet M-SBP-UTS showed a higher net income due to the higher rate of substitution of barley grain by M (Table 1). In 2008, the price of feeds increased, especially grains and straw, affected by the drought and price rises on the international market. Adjusting for these higher prices, the net income per ewe from diets CSC, M-SBP-UTS, CSC-UTS, and MSBP was even higher, between 44 and $86 \%$ higher as 
Table 6. Milking period; total yields of milk fat, protein, and TS; and the milk composition of milking Awassi ewes under different diets in the on-farm experiment

\begin{tabular}{|c|c|c|c|c|c|c|c|}
\hline \multirow{2}{*}{ Variable } & \multicolumn{6}{|c|}{ Treatment $^{1}$} & \multirow{2}{*}{$\begin{array}{l}\text { Initial milk } \\
\operatorname{yield}^{2}(100 \mathrm{~g})\end{array}$} \\
\hline & \multicolumn{2}{|c|}{ Farm 1} & \multicolumn{2}{|c|}{ Farm 2} & \multicolumn{2}{|c|}{ Farm 3} & \\
\hline $\begin{array}{l}\text { Milking period, } \mathrm{d} \\
\text { Total vield of }\end{array}$ & $78 \pm 4$ & $87 \pm 4$ & $90 \pm 4$ & $91 \pm 4$ & $84 \pm 4$ & $90 \pm 4$ & NS \\
\hline Milk, kg & $49.77 \pm 4.34^{\mathrm{b}}$ & $63.77 \pm 4.16^{\mathrm{a}}$ & $56.71 \pm 4.06^{\mathrm{b}}$ & $76.59 \pm 4.07^{\mathrm{a}}$ & $39.22 \pm 4.24^{\mathrm{b}}$ & $55.06 \pm 4.05^{\mathrm{a}}$ & ** \\
\hline $\mathrm{TS}, \mathrm{kg}$ & $8.73 \pm 0.91^{\mathrm{b}}$ & $11.13 \pm 0.88^{\mathrm{a}}$ & $10.49 \pm 0.85^{\mathrm{b}}$ & $13.28 \pm 0.86^{\mathrm{a}}$ & $6.97 \pm 0.89^{\mathrm{b}}$ & $9.94 \pm 0.85^{\mathrm{a}}$ & $* *$ \\
\hline Milk composition & & & & & & & \\
\hline Fat, $\%$ & $5.32 \pm 0.22$ & $5.31 \pm 0.21$ & $4.83 \pm 0.21$ & $5.01 \pm 0.21$ & $5.67 \pm 0.21$ & $5.96 \pm 0.21$ & NS \\
\hline Protein, \% & $6.02 \pm 0.11$ & $6.04 \pm 0.11$ & $6.01 \pm 0.11$ & $6.24 \pm 0.11$ & $6.37 \pm 0.11$ & $6.51 \pm 0.11$ & NS \\
\hline TS, $\%$ & $17.32 \pm 0.81$ & $17.41 \pm 0.78$ & $18.43 \pm 0.76$ & $17.31 \pm 0.76$ & $17.68 \pm 0.79$ & $18.13 \pm 0.76$ & NS \\
\hline Lactose, $\%$ & $5.26 \pm 0.05$ & $5.28 \pm 0.05$ & $5.12 \pm 0.05^{\mathrm{b}}$ & $5.34 \pm 0.05^{\mathrm{a}}$ & $5.00 \pm 0.05$ & $5.06 \pm 0.05$ & NS \\
\hline
\end{tabular}

${ }^{\mathrm{a}, \mathrm{b}}$ Least squares means within a row within the same farm with different superscripts differ $(P<0.05)$.

${ }^{1}$ Control 1, 2, 3 = farmers' traditional diets on farm 1, farm 2, and farm 3, respectively; Exp = experimental diet.

${ }^{2}$ Covariate.

${ }^{* *} P<0.01$.

compared with the control diet, due to higher market prices of yogurt (Table 7). All experimental diets substantially or totally replaced costly barley grain, with feedstuffs of lower market price compared with the control diet. Diets M-SBP-UTS and CSC-UTS also eliminated the use of barley straw, which increases in price in dry years.

The economic performance per ewe, promoted by the alternative experimental diet in the on-farm experiment, was better than the control diet. The costs per ewe per day for the tested diet on the 3 farms were 8.7, 8.5 , and $47.6 \%$ lower than for the control diet, respectively (Table 8).

Although farmers changed diet formulation and decreased the feed offered to decrease costs, the alternative test diets increased the rates of return by more than $30 \%$ in every case. Rationalized feeding enhances production and increases net return because maintenance costs are constant per ewe (Hillers et al., 1979). Molasses, an ingredient available in the region and not used by farmers (Rihawi et al., 2010), proved to be a suitable ingredient in the experimental diets, helping to decrease the use of expensive barley grain. Cotton seed cake, also available in the region, has a high $\mathrm{CP}$ content $(27-38 \%)$ but, as indicated earlier, is not widely used in dairy sheep systems, and can be incorporated to boost the protein content of the diet. Farmers accepted to try this ingredient because of positive information from other farmers that use it. Farmers also reacted positively to the use of UTS in place of barley straw, for which prices soared in 2008. An increased demand for nonconventional feeds could affect their prices. The sensitivity analysis confirmed that costs of the feed per kilogram was lower in the alternative diet compared with the farmers' traditional diets, the economic performance was higher even by fitting $30 \%$ higher prices for M, SBP, and CSC together.

Based on the on-farm results and assuming an average traditional dairy sheep farm in rural areas to have a flock size of 60 ewes, the increase in revenues over the control diet would be, on average, US\$1,770.

\section{CONCLUSIONS}

Balanced diets using low-cost supplements formulated with nonconventional feeds can be options for farmers

Table 7. Total net income (US\$) per ewe and season in the on-station experiment ${ }^{1}$

\begin{tabular}{lccccccc}
\hline & \multicolumn{7}{c}{ Treatment $^{2}$} \\
\cline { 2 - 7 } Year & Control diet & CSC & M-SBP-UTS & CSC-UTS & M-SBP & M-SBP-CSC & M-SBP-VP \\
\hline 2007 & 57.86 & 82.49 & 90.74 & 85.87 & 73.90 & 59.28 & 38.56 \\
2008 & 60.65 & 98.20 & 110.25 & 97.48 & 86.33 & 64.96 & 37.25 \\
\hline${ }^{1}$ Transformed into US\$: 1 US\$ = 46.8 SYP, source: http://www.exchange-rates.org/Rate/USD/SYP (Accessed \\
August 18, 2010). \\
${ }^{2}$ CSC = cotton seed cake-based diet; M = molasses; SBP = sugar beet pulp; UTS = urea-treated wheat straw; \\
VP = vetch pasture.
\end{tabular}


Table 8. Economic values by diets on different farms per milking Awassi ewe (US\$) ${ }^{1}$

\begin{tabular}{|c|c|c|c|c|c|c|}
\hline \multirow[b]{3}{*}{ Economic value } & \multicolumn{6}{|c|}{ Treatment $^{2}$} \\
\hline & \multicolumn{2}{|c|}{ Farm 1} & \multicolumn{2}{|c|}{ Farm 2} & \multicolumn{2}{|c|}{ Farm 3} \\
\hline & Control 1 & Exp & Control 2 & $\operatorname{Exp}$ & Control 3 & Exp \\
\hline Total net income, US\$/ewe per season & -2.29 & 12.78 & 13.14 & 43.46 & -17.99 & 24.23 \\
\hline Total costs, US $\$$ ewe per season & 35.04 & 37.74 & 42.48 & 31.73 & 69.02 & 30.77 \\
\hline Daily cost, US\$/ewe & 0.50 & 0.46 & 0.47 & 0.43 & 0.82 & 0.43 \\
\hline
\end{tabular}

${ }^{1}$ Transformed into US\$: 1 US\$ = 46.8 SYP, source: http://www.exchange-rates.org/Rate/USD/SYP Accessed August 18, 2010.

${ }^{2}$ Control 1, 2, 3 = farmers' traditional diets on farm 1, farm 2, and farm 3, respectively; Exp = experimental diet.

to decrease feeding costs and also enhance the length of the milking period and total yields of milk, fat, protein, and TS, without compromising milk components of quality (fat, protein, TS, and lactose percentages). Diets CSC, M-SBP-UTS, CSC-UTS, and M-SBP, which contained different proportions of conventional and nonconventional feeds tested on-station proved to be most suitable, with increased rates of return up to $30 \%$, as in the case of diet M-SBP-UTS, without affecting milk quality. Enhanced production was more efficiently achieved with alternative diets having CP:ME ratios of 12 to 14, as opposed to the traditional diet used by farmers with CP:ME ratios lower than 10, which depressed milk yields, reflecting a shortage of protein and inefficient use of energy. Thus, the use of agro-industrial byproducts available in the region, particularly $\mathrm{M}$, can partially substitute for the use of costly barley or wheat grains heavily used by farmers, and would considerably decrease feed costs and dependencies on imports in dry years.

\section{ACKNOWLEDGMENTS}

This work was funded by the Austrian Exchange Service (ÖAD, Vienna, Austria) and the International Center for Agricultural Research in the Dry Areas (ICARDA, Aleppo, Syria). The authors express their thanks and appreciation to the farmers who participated in the on-farm experiments.

\section{REFERENCES}

Al-Jassim, R. A. M., D. I. Aziz, K. Zorah, and J. L. Black. 1999. Effect of concentrate feeding on milk yield and body-weight change of Awassi ewes and growth of their lambs. Anim. Sci. 69:441-446.

AOAC. 2000. Official Methods of Analysis. 17th ed. Association of Official Analytical Chemists, Gaithersburg, MD.

Bargo, F., L. D. Muller, E. S. Kolver, and J. E. Delahoy. 2003. Invited review: Production and digestion of supplemented dairy cows on pasture. J. Dairy Sci. 86:1-42.

Ben Salem, H., H. P. S. Makkar, and A. Nefzaoui. 2004. Towards better utilization of non-conventional feed sources by sheep and goats in some African and Asian countries. Options Méditerranéennes CIHEAM 59:177-187.
Ben Salem, H., and T. Smith. 2008. Feeding strategies to increase small ruminant production in dry environments. Small Rumin. Res. 77:174-194.

Ben Salem, H., and I.-A. Znaidi. 2008. Partial replacement of concentrate with tomato pulp and olive cake-based feed blocks as supplements for lambs fed wheat straw. Anim. Feed Sci. Technol. $147: 206-222$.

Bencini, R. 2001. Factors affecting the quality of ewe's milk. Pages 52-83 in Proceedings of the 7th Great Lakes Dairy Sheep Symposium, Eau Claire, WI. Univ. Wisconsin, Madison.

Blache, D., S. K. Maloney, and D. K. Revell. 2008. Use and limitations of alternative feed resources to sustain and improve reproductive performance in sheep and goats. Anim. Feed Sci. Technol. $147: 140-157$.

Cannas, A., A. Nudda, and G. Pulina. 2002. Nutritional strategies to improve lactation persistency in dairy ewes. Pages 17-59 in Proceedings of the 8th Great Lakes Dairy Sheep Symposium, Cornell University, Ithaca, NY. Univ. Wisconsin, Madison.

Carnicella, D., M. Dario, M. C. C. Ayres, V. Laudadio, and C. Dario. 2008. The effect of diet, parity, year and number of kids on milk yield and milk composition in Maltese goat. Small Rumin. Res. 77:71-74.

Cocks, P. S., and A. E. Osman. 1996. Productivity and botanical composition of communally-owned Mediterranean grasslands in the marginal farming areas of north Syria. J. Arid Environ. 33:389 398.

Cowan, R. T., J. J. Robinson, I. McHattie, and K. Pennie. 1981. Effects of protein concentration in the diet on milk yield, change in body composition and the efficiency of utilization of body tissue for milk production in ewes. Anim. Prod. 33:111-120.

Delgado, C., M. Rosegrant, H. Steinfeld, S. Ehui, and C. Courbois. 1999. Livestock to 2020: The Next Food Revolution. International Food Policy Research Institute, Washington, DC.

FAO. 2010. FAOSTAT 2010. FAO Statistics Division. Accessed May 5, 2010. http://faostat.fao.org/site/567/DesktopDefault. aspx?PageID $=567$ \# ancor.

Gabler, M. T., and A. J. Heinrichs. 2003. Dietary protein to metabolizable energy ratios on feed efficiency and structural growth of prepubertal Holstein heifers. J. Dairy Sci. 86:268-274.

Galal, S., O. Gürsoy, and I. Shaat. 2008. Awassi sheep as a genetic resource and efforts for their genetic improvement-A review. Small Rumin. Res. 79:99-108.

Gursoy, O., G. E. Pollott, and K. Kirk. 2001. Milk production and growth performance of a Turkish Awassi flock when outcrossed with Israeli improved Awassi rams. Livest. Prod. Sci. 71:31-36.

Hartwell, B. W., L. Iñiguez, J. Mueller, M. Wurzinger, and W. F. Knaus. 2010. Characterization of Awassi lamb fattening systems: A Syrian case study. Trop. Anim. Health Prod. 42:1573-1578.

Henno, M., M. Ots, I. Jõudu, T. Kaart, and O. Kärt. 2008. Factors affecting the freezing point stability of milk from individual cows. Int. Dairy J. 18:210-215.

Hillers, J. K., J. W. Young, A. E. Freeman, and J. Dommerholt. 1979. Effects of milk composition and production on the feed costs of producing milk. J. Dairy Sci. 62:1662-1664. 
ICAR. 2007. Recording guidelines. International agreement of recording practices. Approved by the General Assembly, 9 June 2006, Kuopio, Finland. International Committee for Animal Recording (ICAR) newsletter.

Iñiguez, L. 2005. Characterization of Small Ruminant Breeds in West Asia, North Africa. Vol. 1 West Asia. 1st ed. International Center for Agricultural Research in the Dry Areas, Aleppo, Syria.

Iñiguez, L., and M. Hilali. 2009. Evaluation of Awassi genotypes for improved milk production in Syria. Livest. Sci. 120:232-239.

Jaime, C., and A. Purroy. 1995. Level and quality of protein in rations for lactating ewes. Ann. Zootech. 44:135-142.

Li, J., K. Jo Min, T. Otake, and T. Van Voorhis. 2008. Inventory and investment in setup and quality operations under return on investment maximization. Eur. J. Oper. Res. 185:593-605.

Lu, C. D., J. R. Kawas, and O. G. Mahgoub. 2005. Fibre digestion and utilization in goats. Small Rumin. Res. 60:45-52.

MAFF. 1987. Energy Allowances and Feeding Systems for Ruminants Reference book 433. HMSO, London, UK.

Molle, G., M. Decandia, A. Cabiddu, S. Y. Landau, and A. Cannas. 2008. An update on the nutrition of dairy sheep grazing Mediterranean pastures. Small Rumin. Res. 77:93-112.

Murphy, J. J., and F. O'Mara. 1993. Nutritional manipulation of milk protein concentration and its impact on the dairy industry. Livest. Prod. Sci. 35:117-134.

Nefzaoui, A., A. Salman, and M. El-Mourid. 2008. Sheep husbandry and reproduction improvement in low-rainfall areas of West Asia and North Africa. International Center for Agricultural Research in the Dry Areas, Aleppo, Syria.

Nudda, A., R. Bencini, S. Mijatovic, and G. Pulina. 2002. The yield and composition of milk in Sarda, Awassi, and Merino sheep milked unilaterally at different frequencies. J. Dairy Sci. 85:2879-2884.

Nurfeta, A., A. Tolera, L. O. Eik, and F. Sundstøl. 2009. Effect of enset (Ensete ventricosum) leaf supplementation on feed intake, digestibility, nitrogen utilization and body weight gain of sheep fed untreated or urea and calcium oxide-treated wheat straw. Livest. Sci. 122:134-142.

Osman, A. E., F. Bahhady, N. Hassan, F. Ghassali, and T. A. L. Ibrahim. 2006. Livestock production and economic implications from augmenting degraded rangeland with Atriplex halimus and Salsola vermiculata in northwest Syria. J. Arid Environ. 65:474-490.
Peel, C. J., and D. E. Bauman. 1987. Somatotropin and lactation. J Dairy Sci. 70:474-486.

Preston, T. R. 1988. Molasses as animal feed: An overview. Page 319 in Sugarcane as feed, FAO Animal Production and Health Papers 72, Proceedings of an FAO Expert Consultation, Santo Domingo, Dominican Republic. FAO Animal Production and Health Papers 72. FAO, Rome, Italy.

Rihawi, S., L. Iñiguez, W. F. Knaus, M. Zaklouta, M. Wurzinger, J. Soelkner, A. Larbi, and M. A. D. Bomfim. 2010. Fattening performance of lambs of different Awassi genotypes, fed under costreducing diets and contrasting housing conditions. Small Rumin. Res. 94:38-44.

Șahin, A., M. Keskin, O. Biçer, and S. Gül. 2003. Diet selection by Awassi lambs fed individually in a cafeteria feeding system. Livest. Prod. Sci. 82:163-170.

Schei, I., H. Volden, and L. Bævre. 2005. Effects of energy balance and metabolizable protein level on tissue mobilization and milk performance of dairy cows in early lactation. Livest. Prod. Sci. 95:35-47.

Settivari, R. S., J. N. Spain, M. R. Ellersieck, J. C. Byatt, R. J. Collier, and D. E. Spiers. 2007. Relationship of thermal status to productivity in heat-stressed dairy cows given recombinant bovine somatotropin. J. Dairy Sci. 90:1265-1280.

Tilley, J. M. A., and R. A. Terry. 1963. A two-stage technique for the in vitro digestion of forage crops. J. Br. Grassl. Soc. 18:104-111.

Treacher, T. T., and G. Caja. 2002. Nutrition during lactation. Pages 213-236 in Sheep Nutrition. M. Freer and H. Dove, ed. CAB International, New York, NY.

Van Soest, P. J. 1994. Nutritional Ecology of the Ruminant. 2nd ed. Cornell University Press, Ithaca, NY.

Van Soest, P. J., J. B. Robertson, and B. A. Lewis. 1991. Methods for dietary fiber, neutral detergent fiber, and nonstarch polysaccharides in relation to animal nutrition. J. Dairy Sci. 74:3583-3597.

Vasta, V., A. Nudda, A. Cannas, M. Lanza, and A. Priolo. 2008. Alternative feed resources and their effects on the quality of meat and milk from small ruminants. Anim. Feed Sci. Technol. 147:223246. 